\title{
Evaluasi kesesuaian lokasi bank BRI di wilayah kantor cabang Setiabudi Kota Bandung
}

\section{Moh. Dendy F B dan Rendra Zainal Maliki}

${ }^{1,2}$ Program Studi Pendidikan Geografi, Sekolah Pasca Sarjana, Universitas Pendidikan Indonesia

Email Koresponden: dendy.fathurahman@gmail.com

Diterima: Juni 2018 /Refisi: Agustus 2018 Disetujui: 19 September 2018

() 2018 Fakultas Geografi UGM dan Ikatan Geograf Indonesia (IGI)

\begin{abstract}
Abstrak Penentuan lokasi Bank yang dapat dijangkau masyarakat dapat membantu dalam peningkatan perekonomian. Saat ini, lokasi Bank di Kota Bandung belum sepenuhnya sesuai dengan kebutuhan masyarakat. Tujuan penelitian ini yaitu mengidentifikasi kesesuaian lokasi Kantor Cabang Pembantu (KCP) Bank BRI di Wilayah Unit Kerja Cabang Setiabudi Kota Bandung dengan Menggunakan Aplikasi Sistem Informasi Geografis. Metode untuk mengumpulkan data dalam penelitian ini yaitu observasi, pengukuran lapangan, geocoding, metode pengharkatan dan perengkingan serta yang terakhir adalah wawancara. Parameter yang digunakan dalam analisis penelitian ini adalah lokasi daerah industri, penggunaan lahan, daerah perdagangan, daerah pendidikan, jumlah penduduk, kepadatan penduduk dan kelas jalan. Berdasarkan hasil analisis didapatkan kesimpulan bahwa lokasi KCP Bank BRI di wilayah unit kerja Kantor Cabang Setiabudi baru yaitu KCP BRI Lembang, KCP BRI Cihampelas dan KCP BRI Surya Sumantri tidak seluruhnya mendapat klasifikasi sangat sesuai. Berdasarkan hasil overlay terdapat dua KCP yang mendapat kategori sangat sesuai yaitu KCP Cihampelas yang berada di wilayah Kecamatan Coblong dan KCP Surya Sumantri yang berada di wilayah Sukajadi. Selanjutnya terdapat satu daerah lagi yang mendapat klasifikasi sangat sesuai apabila dibangun KCP BRI yaitu di wilayah Kecamatan Sukasari, Akan tetapi di wilayah Sukasari terdapat Kantor Cabang BRI Setiabudi yang merupakan induk dari tiga KCP.
\end{abstract}

Keywords: evaluasi kesesuaian lokasi, kantor cabang pembantu (kcp), bank bri, kota bandung.

Abstract The determination of Bank locations that can be accessed by the community can help in improving the economy. Nowadays, Bank location in Bandung is not yet available in accordance with the needs of the community. The purpose of this study was to describe the suitability of the location of branch offices (KCP) Bank BRI in the Area Unit Setiabudi Branch Bandung using Geographic Information System Application. Method for collecting data in this research was observation, field measurement, geocoding, scoring, range, and interview. The parameters used in this research analysis were the location of the industrials area, lands use, trades area, educations area, populations, population density, and roads class. Based on analysis of Bank BRI KCP location determination using Geographic Information Systems concluded that KCP Bank BRI area in new Setiabudi unit branch office were KCP BRI Lembang, KCP BRI Cihampelas dan KCP BRI Surya Sumantri not all got the very appropriate classifications. Based on the results there were two KCP overlay that got very appropriate category KCP Cihampelas located in the districts of Coblong and KCP Surya Sumantri located in the district of Sukajadi. Furthermore, there was one more area that got very appropriate classification if built BRI KCP was namely in the districts of Sukasari. But in the area Sukasari BRI Branch Office Setiabudi which is the center of three KCP.

Keywords: conformity evaluation locations, branch office, bank bri, bandung city.

\section{PENDAHULUAN}

Bank didirikan dengan maksud untuk membantu mendorong pertumbuhan perekonomian dan pembangunan daerah di berbagai bidang serta sebagai salah satu sumber pendapatan daerah dalam rangka meningkatkan taraf hidup masyarakat. Keberhasilan suatu pembangunan di daerah terlihat dari pertumbuhan ekonomi daerah tersebut, dimana hal itu sangat dipengaruhi oleh kondisi perbankannya. Mengalirnya kredit kepada masyarakat yang digunakan untuk melakukan investasi dan kegiatan seharihari akan mendorong produktifitas daerah yang akan meningkatkan kegiatan perekonomian daerah, sehingga industri perbankan sebagai lembaga perantara keuntungan merupakan lembaga penting dalam perekonomian (Syavitra, 2009).
Pengertian Bank menurut Undang-Undang Republik Indonesia Nomor 10 Tahun 1998 Tanggal 10 November 1998 tentang Perbankan, bahwa yang dimaksud dengan Bank adalah badan usaha yang menghimpun dana dari masyarakat dalam bentuk simpanan dan menyalurkannya kepada masyarakat dalam bentuk kredit dan atau bentuk-bentuk lainnya dalam rangka meningkatkan taraf hidup rakyat banyak.

Kegiatan perekonomian di suatu tempat, wilayah, maupun Negara ditandai dengan tumbuh kembangnya pusat-pusat niaga maupun industri yang berdiri di lokasi-lokasi yang strategis. Pertumbuhan ekonomi yang baik seperti pasar, mall, pertokoan, dan pusat perekonomian lain dapat menjadikan sebagai tolak ukur bahwa daerah tersebut dapat dikatakan baik 
secara finansial. Secara tidak langsung hal tersebut berkaitan dengan keberadaan atau letak suatu wilayah yang dalam istilah geografi disebut dengan lokasi.

Capello (2011) menjelaskan bahwa teori lokasi memberikan keuntungan secara ekonomi kepada para pelaku ekonomi. Lokasi yang sesuai dengan kebutuhan pasar akan memudahkan transaksi seperti keberadaan suatu Bank sehingga dapat membantu kebutuhan masyarakat. Penentuan lokasi menjadi fokus utama dalam geografi. Seperti yang dikemukakan oleh Capello (2011) lokasi yang menguntungkan secara geografis yaitu aksesibilitas yang mudah atau sulit dari suatu daerah dan persediaan bahan baku yang tinggu atau rendah..

Kottler (1996) menempatkan sistem delivery atau place sebagai salah satu dari empat bauran pemasaran. Dalam beberapa hal seringkali perusahaan hanya mengkonsentrasikan pada tiga bauran pemasaran yaitu product, promotion, dan price sedangkan place sering terabaikan. Bagi Bank place merupakan salah satu sarana untuk menyediakan produknya bagi nasabah di suatu tempat. Bank seringkali menghadapi masalah pengadaan atau penyebaran tempat-tempat yang tepat dalam penyaluran produknya.

Keputusan pemilihan place merupakan suatu keputusan yang memerlukan pertimbangan matang dan mungkin merupakan salah satu yang sukar dihadapi manajemen suatu Bank. Dalam menetapkan place, Bank terlebih dahulu perlu mengevaluasi dan menentukan cakupan geografis yang paling tepat serta jenis cabang untuk kebutuhan jasa bagi target nasabah yang dilayani.

Dari penjelasan di atas, tentunya pihak perbankan memiliki strategi dalam menentukan suatu lokasi berdasarkan kebutuhan masyarakat. Pihak Bank selalu memperhitungkan dengan matang apabila akan mendirikan suatu Bank. Penentuan lokasi yang tepat akan memberikan keuntungan bagi pihak Bank dan nasabah. Di daerah perkotaan biasa berdiri beberapa Bank yang saling berdampingan satu sama lain. Dengan banyaknya Bank yang saling berdampingan dapat disimpulkan bahwa daerah tersebut memiliki keunggulan dalam pangsa pasar yang besar.

Tujuan dari strategi lokasi adalah untuk memaksimalkan keuntungan lokasi perusahaan. Semakin besar sebuah pusat pelayanan maka semakin besar dan luas jangkauan dan pusat pelayanan dengan hirarki yang lebih rendah. Penetuan lokasi sangat penting dalam sebuah kegiatan ekonomi. Seperti yang dijelaskan oleh Mohamed dkk (2015) bahwa bahwa lokasi adalah salah satu karakteristik lahan yang sangat penting dalam menganalisis pertumbuhan ekonomi. - Dalam menentukan keberadaan atau lokasi yang strategis suatu Bank dapat menggunakan teknik analisis salah satunya adalah sistem informasi geografis (SIG).

Menurut Chang (2002) Sistem Informasi Geografis adalah system komputer untukmenangkap, menyimpan, mempertanyakan, menganalisis, dan menampilkan data geografis. Seperti teknologi informasi lainnya, GIS dapat dibagi menjadi empat komponen berikut: sistem komputer, perangkat lunak GIS, peralatan otak, dan infrastruktur. Sistem Informasi Geografis adalah sebuah sistem komputer untuk mengumpulkan, menyimpan, menganalisis, dan menampilkan data geografis.

Lebih lanjut Kavita (2011) mengemukakan bahwa Teknologi GIS dapat membantu menjawab pertanyaan dan memecahkan masalah dengan melihat data spasial secara real time dengan cara yang cepat dipahami dan mudah dibagikan dan menampilkan informasi yang memastikan pengambilan keputusan lebih cepat. Informasi data spasial yang didapatkan dari sistem informasi geografi (SIG) digunakan untuk menentukan lokasi suatu Bank. Pineda et al (2017) menjelaskan bahwa Geographic information system dapat membantu perusahaan, insitusi ataupun yang lainnya melakukan pemasaran produknya.

Perkembangan kemajuan teknologi informasi saat ini telah membuat SIG tidak sekedar menjadi tren teknologi pemetaan semata, tetapi sudah menjadi salah satu kebutuhan informasi (Hutagaol, 2015). SIG tidak hanya digunakan untuk analisis lokasi tetapi juga untuk sektor ritel lain, seperti persoalan manajemen, pemasaran dan komunikasi dan pemasaran (Benoit dan Clarke, 1997).

Penggunaan SIG dapat diintegrasikan secara bersama dengan cara menggabungkan data yang diperoleh dari penginderaan jauh kemudian dianalisis menggunakan SIG untuk menghasilkan informasi baru. Mohamed dkk (2015) mengemukakan bahwa GIS memungkinkan penanganan data spasial dan non-spasial untuk membangun peta tematik yang menggambarkan berbagai informasi yang berkaitan dengan kegiatan ekonomi. Informasi data spasial yang dihasilkan dapat berupa penentuan lokasi baru, daerah rawan bencana, penentuan pemukiman, jalur transportasi alternatif, dan lain-lain sesuai dengan kebutuhan pengguna. Pengguanaan SIG dapat juga membantu dalam menentukan evaluasi kesesuaian lokasi Bank yang sudah ada maupun yang akan dikembangkan.

Kota Bandung merupakan ibukota provinsi Jawa Barat yang memiliki tingkat perekonomian tinggi. Faktor ekonomi tersebut dapat dibantu dengan keberadaan suatu Bank. Penentuan lokasi Bank yang dapat dijangkau oleh masyarakat bisa membantu dalam perekonomian Kota Bandung, salah satunya adalah Bank BRI. Bank BRI di Kota Bandung terdapat beberapa kriteria mulai Kantor Wilayah, Kantor Cabang, Kantor Cabang Pembantu sampai satuan yang terkecil yaitu unit.

Sistem Informasi Geografis dapat digunakan untuk menganalisis lokasi baru apabila pihak Bank ingin mengembangkan atau menambah Kantor Cabang Pembantu di Kota Bandung. Fauzi dkk (2009) mengemukakan, pemanfaatan Sistem Informasi Geografis (SIG) menjanjikan pengelolaan sumber 
daya dan pembuatan model terutama model kuantitatf menjadi lebih mudah dan sederhana. Hasil analisis spasial yang dilakukan dengan SIG dapat dijadikan sebagai dasar yang kuat (teknis) bagi suatu pengambilan keputusan atau pembuatan suatu kebijakan (Prahasta, 2009).

Adapun tujuan dalam penulisan artikel ini yaitu untuk mendeskripsikan dalam menentukan Kesesuaian Lokasi Baru Kantor Cabang Pembantu (KCP) Bank BRI di Wilayah Unit Kerja Cabang Setiabudi Kota Bandung dengan Menggunakan Aplikasi Sistem Informasi Geografis.

\section{METODE}

Menurut Sugiyono (2011) lokasi penelitian menunjukan pada pengertian tempat atau lokasi penelitian yang dirincikan oleh adanya unsur yaitu pelaku, tempat kegiatan yang dapat diobservasi. Adapun lokasi penelitian ini adalah Kota Bandung. Secara Geografis Kota Bandung terletak 6 55’02,87” LU dan $107^{\circ} 37^{\prime} 08.84$ LS dan terletak di elavasi $2458 \mathrm{mdpl}$.

Wilayah Kota Bandung merupakan wilayah yang memiliki pertumbuhan ekonomi sangat pesat. Hal tersebut berdasarkan pada perkembangan jasa perbankan di Kota Bandung yang semakin berkembang, salah satunya adalah Bank Rakyat Indonesia (BRI). Di Kota Bandung banyak terdapat unit-unit Bank BRI yang dimulai dari kantor wilayah, kantor cabang, kantor cabang pembantu, kantor unit, dan teras. Untuk di wilayah Setiabudi sendiri terdapat kantor cabang BRI. Kantor Cabang BRI Setiabudi merupakan salah satu cabang dari kantor Wilayah Bank BRI Bandung, yang terletak di Jl. Dokter Setiabudhi No.170 F-G, Bandung. Kantor Cabang BRI Setiabudi memiliki 3 Unit kantor cabang pembantu, yaitu kantor cabang pembantu Cihampelas yang terletak di jalan Jl. Cihampelas No.186, Bandung, kantor cabang pembantu Setra Sari Jl. Surya Sumantri No.34A Bandung, dan kantor cabang pembantu Lembang yang terletak di Jl. Raya Lembang No. 436-438, Lembang.

Pertimbangan yang menjadikan dasar Kota Bandung dijadikan sebagai lokasi serta subjek dalam penelitian dikarenakan Kota ini memliki pertumbuhan yang sangat pesat. Kota Bandung juga memiliki banyak pusat-pusat kegiatan seperti pusat perdagangan, industri, pendidikan, dan jasa. Sebagai kawasan yang strategis selain sebagai pusat pendidikan, perdagangan, dan jasa serta aksesibilitas yang baik tentunya akan menjadikan Kota Bandung memiliki banyak keterkaitan dengan sektor ekonomi. Perkembangan Kota Bandung juga tidak terlepas dari sebaran penduduk yang padat dan jumlah jasa perbankan yang semakin banyak untuk memenuhi kebutuhan masyarakat.

Turk dkk (2014) menyatakan saat ini, SIG digunakan dalam Sistem Informasi Pemasaran sebagai alat untuk proses pengambilan keputusan. Dalam kebutuhan ekonomi dibutuhkan rencana pemasaran yang dapat dikembangkan dengan memanfaatkan teknologi SIG.
Seperti yang dikemukakan oleh Turk dkk (2014) bahwa sistem catatan internal dapat menyediakan informasi tentang faktor internal seperti penjualan, biaya dan arus kas.

Kebutuhan masyarakat akan jasa perbankan membuat timbulnya persaingan bank di daerah Kota Bandung semakin ketat. Banyaknya pendirian Bank khususnya di wilayah Kota Bandung tidak lepas dari manfaat dan kerugiannya terutama masalah lahan dan peruntukannya. Disamping memperhatikan kesesuaian lahannya juga harus ada surat izin tempat usaha yang dikeluarkan baik oleh Pemerintah Daerah/ Kota. Untuk itu, penelitian ini mengenai penentuan dalam menganalisis kesesuaian lokasi kantor cabang pembantu BRI di wilayah unit kerja kantor cabang Setiabudi Kota Bandung.

Waktu penelitian ini dilakukan secara bertahap dari mulai proses pengumpulan data sampai proses survey/observasi ke lapangan. Tahap pengumpulan data dilakukan dari mulai tanggal 10 Maret sampai 10 April 2016 yaitu dengan cara mencari sumber data yang sesuai dengan kajian penelitian. Tahap terakhir yaitu survey/observasi ke lapangan dilaksanakan pada bulan Maret sampai April 2016.

Bahan yang diperlukan dalam penelitian ini adalah peta lokasi daerah industri, peta lokasi penggunaan lahan, peta lokasi daerah perdagangan, peta lokasi daerah pendidikan, peta jumlah penduduk, peta pendapatan penduduk, dan peta kelas jalan.

Peralatan yang digunakan pada penelitian iniberupa hardware dan software. Hardware yang digunakan pada penelitian ini diantaranya ialah leptop, global positioning system (GPS), printer, kamera digital dan alat tulis. Untuk software yang digunakan diantaranya ialah ArcGIS version 10.1, Google Earth, dan Microsoft office 2010.

Jenis data pada penelitian ini dibagi menjadi dua yaitu data primer dan data sekunder. Akan tetapi data pada penelitian ini ditambah data yang didapat melalui survey lapangan.

Data primer pada penelitian ini didapatkan secara langsung di lapangan. Data primer pada penelitian ini merupakan interpretasi dari citra google earth serta dari beberapa peta parameter yang sudah didapatkan. Hasil interpretasi tersebut kemudian disamakan dengan data lapangan dan disesuaikan dengan parameter-parameter yang sudah ditentukan agar data tidak menyimpang.

Data sekunder pada penelitian ini diperoleh dari berbagai sember diantaranya dari jurnal hasil penelitian, kajian literatur, serta dokumen-dokumen dari berbagai instansi. Sumber yang terkait bisa dari instansi pemerintah, pendidikan maupun swasta. Dalam studi ini, instansi yang akan dituju adalah Kantor Cabang Bank BRI Setiabudi Kota Bandung, BAPEDDA Kota Bandung dan Kabupaten Bandung Barat, BPS Kota Bandung dan Kabupaten Bandung Barat.

Survey dilakukan untuk pengamatan langsung di lapangan. Data dari citra penginderaan jauh dan data 


\begin{tabular}{|c|c|c|c|c|c|c|}
\hline \multicolumn{7}{|c|}{ Tabel 1. Sumber Data Penelitian } \\
\hline \multirow{2}{*}{ No } & \multirow{2}{*}{\multicolumn{2}{|c|}{ Peta parameter }} & \multicolumn{3}{|c|}{ Sumber data } & \multirow{2}{*}{ Keterangan } \\
\hline & & & Citra PJ & Data Sekunder & Survey & \\
\hline 1. & Peta Lokasi Daeral & dustri & $\sqrt{ }$ & $\sqrt{ }$ & $\sqrt{ }$ & Pusdalitbang Pemprop Jawa Barat \\
\hline 2. & Peta Penggunaan I & & $\sqrt{ }$ & $\sqrt{ }$ & $\sqrt{ }$ & Pusdalitbang Pemprop Jawa Barat \\
\hline 3. & $\begin{array}{l}\text { Peta Lokasi } \\
\text { Perdagangan }\end{array}$ & Daerah & $\sqrt{ }$ & $\sqrt{ }$ & $\sqrt{ }$ & $\begin{array}{l}\text { Citra Google Earth dan PD Pasar } \\
\text { Bermartabat }\end{array}$ \\
\hline 4. & $\begin{array}{l}\text { Peta Lokasi } \\
\text { Pendidikan }\end{array}$ & Daerah & $\sqrt{ }$ & $\sqrt{ }$ & $\sqrt{ }$ & $\begin{array}{l}\text { Citra Google Earth dan } \\
\text { Pusdalitbang Pemprop Jawa Barat }\end{array}$ \\
\hline 5. & Peta Jumlah Pend & & - & $\sqrt{ }$ & $\sqrt{ }$ & BPS \\
\hline 6. & $\begin{array}{l}\text { Peta Tingkat } \\
\text { Penduduk Pendud }\end{array}$ & dapatan & - & $\sqrt{ }$ & $\sqrt{ }$ & BPS \\
\hline 7 & Peta Kelas Jalan & & - & $\sqrt{ }$ & $\sqrt{ }$ & DISHUB dan Citra Google Earth \\
\hline 8. & Kesesuaian Lokasi & & $\sqrt{ }$ & - & $\sqrt{ }$ & Citra Google Earth dan BPS \\
\hline
\end{tabular}

Sumber: Hasil Pemikiran, 2016

sekunder kemudian dicocokan langsung oleh peneliti. Beberapa data yang diperlukan dalam penelitian ini dan sumber data dapat dilihat pada Tabel 1 berikut.

Populasi dalam penelitian ini adalah seluruh kantor cabang pembantu yang berada di wilayah kerja kantor cabang pembantu Bank BRI Setiabudi Kota Bandung. Berdasarkan data yang diperoleh dari data Bank BRI Pusat, Kantor cabang pembantu di wilayah kerja Kantor cabang Bank BRI Setiabudi terdapat 3 unit yaitu kantor cabang pembantu Cihampelas yang terletak di Jl. Cihampelas No. 186 Bandung, Kantor cabang pembantu Setra Sari yang terletak di Jl. Sumantri No. 34A Bandung, dan Kantor cabang pembantu Lembang yang terletak di Jl. Raya Lembang No.436-438, Lembang.

Berdasarkan pernyataan di atas, maka dapat disimpulkan sampel dalam penelitian ini adalah seluruh kantor cabang pembantu yang berada di wilayah kerja kantor cabang BRI Setiabudi, yaitu KCP Cihampelas, KCP Setra Sari dan KCP Lembang. Sampel mempunyai tujuan untuk menyederhanakan proses penelitian pada suatu populasi, dimana alasan penggunaan sampel adalah efisiensi tenaga, efisiensi waktu, efisiensi biaya.

Observasi atau pengamatan langsung di lapangan pada penelitian ini dimaksudkan untuk mengetahui secara langsung suatau peristiwa dan memperoleh data yang tidak mungkin diperoleh dari pengumpulan data sekunder. Pengamatan langsung dalam penelitian ini ditujukan untuk mengamati dan mendokumentasikan seluruh KCP Bank BRI yang berada di wilayah kerja KC BRI Setiabudi.

Teknik pengukuran lapangan ini digunakan untuk mengumpulkan data tentang lokasi (koordinat X-Y) dari seluruh KCP yang berada di wilayah kerja kantor cabang Bank BRI Setiabudi. Alat yang digunakan untuk menentukan koordinat lokasi Bank BRI adalah GPS (Global Positioning System). Di samping data koordinat lokasi, peneliti juga melakukan pengamatan tentang lokasi yang di prediksi dengan cara merekam/memfoto setiap lokasi tersebut.
Teknik ini digunakan untuk mengkonversi alamat ke lokasi titik tertentu di jaringan jalan berdasarkan lokasi dari alamat sebagaimana ditetapkan dalam data referensi informasi jalan. Mempertimbangkan berbagai jenis parameter alamat yang dapat melakukan Geocoding untuk mencocokkan daerah yang diprediksi dapat di bangun lokasi kantor cabang pembantu Bank BRI yang ada di wilayah kerja kantor Cabang Setiabudi Kota Bandung. Geocoding menggabungkan informasi peta dengan alamat jalan sehingga titik dapat berada pada peta dasar untuk setiap lokasi sesuai alamat.

Teknik scoring merupakan suatu cara menilai hirarki jalan maupun tingkat pelayanan (Level of Service) terhadap lokasi-lokasi kantor cabang pembantu Bank BRI yang berada di wilayah kerja kantor Cabang Setiabudi Kota Bandung dengan memberikan nilai atau harkat pada masing-masing parameter dan kriterianya, sehingga dapat dihitung nilainya. Teknik scoring menggunakan beberapa parameter penentu, yang sesuai dengan kondisi fisik, sosial dan ekonomi di daerah penelitian dengan besaran harkat yang disesuaikan dengan kontribusi relatif dari peubah tersebut terhadap kesesuaian lokasi yang diprediksi dapat dibangun lokasi kantor cabang pembantu Bank BRI yang berada di wilayah kerja kantor Cabang Setiabudi Kota Bandung. Semakin tinggi kontribusi kesesuaiannya bagi nasabah, maka semakin tinggi pula harkat yang telah ditentukan. Metode penelitian ini digunakan untuk menganalisis hirarki klasifikasi fungsi jalan, tingkat pelayanan (Level of Service) ruas jalan. Analisis hirarki klasifikasi fungsi jalan, menggunakan data sekunder, dimana peta hirarki klasifikasi fungsi jalan tersebut memiliki unit-unit fungsi jalan yang kemudian diharkat (di score) sesuai dengan kontribusi relatif untuk lokasi kantor cabang pembantu Bank BRI. Analisis tingkat pelayanan (Level of Service) ruas jalan menggunakan data primer yang berupa perhitungan penelitian di lapangan.

Wawancara 
Teknik ini digunakan untuk mengumpulkan data-data pendukung, terutama tetang parameterparameter yang dapat membantu dalam penentuan atau mengevaluasi kesesuaian lokasi Bank BRI.

Data yang telah terkumpul baik melalui pengumpulan data primer maupun sekunder, kemudian diolah melalui tahapan sebagai berikut:

Semua data yang diperoleh diolah dengan melakukan reduksi data atau memilah data-data yang benar-benar dibutuhkan dan mendukung kegiatan penelitian serta memisahkan data-data yang sekiranya tidak mendukung penelitian sehingga mudah dalam menganalisis data tersebut.

Data primer yang bersifat kualitatif dari hasil survey diolah dengan membuat ringkasan data kemudian dipilah nama yang termasuk satuan informasi dam lainnya, kemudian dilakukan pengkodean tiap satuan.

Klasifikasi yaitu proses pemilahan data sesuai analisis dana kebutuhan penelitian.. Data yang telah diperoleh melalui pengumpulan data primer maupun sekunder, diolah serta diklasifikasikan berdasarkan jenisnya.

Tahap pengelompokan data primer maupun sekunder dengan memasukkan data-data tersebut dalam bentuk tabel.

Teknik analisis yang digunakan pada penelitian ini adalah analisis overlay dan buffering. Analisis overlay adalah proses integrasi data dari lapisan-lapisan layer yang berbeda. Buffering adalah proses yang membangun lapisan pendukung sekitar layer dalam jarak tertentu untuk menentukan dekatnya hubungan antara sifat bagian yang ada. Unit analisis atau penyajian data spasial yang digunakan dalam penelitian ini adalah dalam bentuk titik dan area.

\section{Parameter Kesesuaian Lokasi Kantor Cabang Pembantu Bank Bri Di Wilayah Kerja Kantor Cabang Setiabudi Kota Bandung}

Penilaian parameter yang dilakukan untuk mengevaluasi kesesuaian lokasi KCP BRI baru adalah dengan menggunakan metode penskoran setiap

parameter diberi faktor pembobot sesuai dengan besar pengaruhnya terhadap penentuan lokasi KCP. Besarnya masing-masing faktor pembobot parameter-parameter tersebut dapat dilihat pada Tabel 2.

Tabel 2. Parameter Evaluasi Kesesuaian Lokasi Kantor Cabang Pembantu (KCP) Bank BRI di Wilayah Kerja Kantor Cabang Setiabudi Kota Bandung

\begin{tabular}{lc}
$\begin{array}{c}\text { Parameter Evaluasi Sebaran Lokasi } \\
\text { Stasiun Pelayanan Bahan Bakar Umum }\end{array}$ & $\begin{array}{c}\text { Faktor } \\
\text { Pembobot }\end{array}$ \\
\hline Lokasi Daerah Industri & 3 \\
Lokasi Penggunaan Lahan & 3 \\
Lokasi Daerah Perdagangan & 3 \\
Lokasi Daerah Pendidikan & 3 \\
Jumlah Penduduk & 3 \\
Tingkat Pendapatan Penduduk & 3 \\
Kelas Jalan & 2 \\
Kesesuaian Lokasi & 3 \\
\hline
\end{tabular}

Sumber: Hasil Pemikiran, 2016

Berdasarkan Tabel 2, dapat disimpulkan bahwa parameter evaluasi sebaran lokasi Kantor Cabang Pembantu (KCP) Bank BRI di wilayah kerja Bank BRI Cabang Setiabudi di Kota Bandung terdiri dari 9 jenis Parameter, yaitu lokasi daerah industri, penggunaan lahan, perdagangan, pendidikan, jumlah penduduk, tingkat pendapatan penduduk, kelas jalan, dan yang terakhir adalah kesesuaian lokasi. parameter yang digunakan untuk evaluasi sebaran lokasi kantor cabang pembantu Bank BRI tersebut kemudian di overlay sehingga memperoleh lokasi yang strategis.

\section{Kelas Kesesuaian Lokasi Bank}

Pentingnya mengetahui teori lokasi penentuan Kantor Cabang Pembantu Bank BRI adalah peletak dasar antara konsep ekonomi dan spasial. Lokasi yang potensial untuk penempatan Bank, yaitu lokasi yang menguntungkan secara ekonomis maupun kenyamanan konsumen dan sangat terjangaku oleh nasabah (Tabel 3).

Tabel 3. Kesesuaian Lokasi Kantor

Cabang Pembantu Bank BRI

\begin{tabular}{cclc}
\hline Kelas & Kriteria & Keterangan & Harkat Total \\
\hline S1 & Sangat sesuai & $\begin{array}{l}\text { Merupakan lokasi yang sangat menguntungkan baik secara } \\
\text { ekonomi maupun kenyamanan konsumen dan sangat terjangkau } \\
\text { oleh nasabah }\end{array}$ & $36-46$ \\
S2 & Sesuai & $\begin{array}{l}\text { Lokasi yang menguntungkan secara ekonomi dan konsumen } \\
\text { cukup nyaman serta terjangkau oleh nasabah }\end{array}$ & $25-35$ \\
S3 & Kurang Sesuai & $\begin{array}{l}\text { Lokasi kurang menguntungkan secara ekonomi dan kurang } \\
\text { nyaman bagi konsumen serta kurang terjangkau oleh nasabah }\end{array}$ & $14-24$ \\
N & Tidak Sesuai & $\begin{array}{l}\text { Lokasi yang tidak menguntungkan secara ekonomi maupun } \\
\text { kenyamanan konsumen dan tidak terjangkau oleh nasabah }\end{array}$ & $<13$ \\
\hline
\end{tabular}

Sumber: Hasil Pemikiran, 2016

188| https://jurnal.ugm.ac.id/mgi 
Evaluasi sebaran lokasi Kantor Cabang Pembantu Bank BRI yang berada di wilayah kerja Kantor Cabang BRI Setiabudi dapat dievaluasi menggunakan parameter-parameter yang dianggap berpengaruh dalam keberadaan suatu Bank. Peta parameter yang digunakan untuk menentukan kesesuaian sebaran lokasi Bank sebagai berikut:

Parameter kesesuaian lokasi daerah industri mendapat bobot 3 di karenakan faktor tersebut secara langsung berhubungan dengan segmen pasar khususnya ekonomi makro. Lokasi Kantor Cabang Pembantu (KCP) yang dekat dengan industri secara finansial akan menguntungkan pihak Bank. Jarak Bank yang dekat dengan industri akan membantu pihak industri apabila akan bertransaksi yang berhubungan dengan keuangan. Lokasi Bank yang dekat dengan daerah industri juga akan dapat menambah pemasukan pihak Bank.

Tabel 4. Kriteria Penskoran Parameter Lokasi Daerah Industri

\begin{tabular}{llc}
\hline \multicolumn{1}{c}{ Kriteria } & \multicolumn{1}{c}{ Keterangan } & Skor \\
\hline Dekat & Sangat Sesuai & 3 \\
Sedang & Sesuai & 2 \\
Jauh & Kurang Sesuai & 1 \\
\hline
\end{tabular}

Sumber: Hasil Pemikiran, 2016

Berdasarkan Tabel 4, maka dapat disimpulkan bahwa kriteria penskoran parameter lokasi daerah industri dengan klasifikasi industri besar dengan keterangan sangat sesuai, lokasi daerah industri menengah dengan keterangan sesuai, dan lokasi daerah industri kecil dengan kriteria kurang sesuai.

Lokasi penggunaan lahan mendapat bobot 3 di karenakan faktor tersebut memiliki pengaruh pada keberadaan Bank. Lokasi Bank yang berada pada daerah dekat dengan perkantoran atau pemukiman dapat dijadikan pertimbangan jika pihak Bank akan menambah kantor cabang pembantu baru. Lokasi perkantoran perlu didukung dengan keberadaan Bank apabila nasabah akan melakukan transaksi keuangan.

Tabel 5. Kriteria Penskoran Parameter Lokasi Penggunaan Lahan

\begin{tabular}{llc}
\hline \multicolumn{1}{c}{ Kriteria } & \multicolumn{1}{c}{ Keterangan } & Skor \\
\hline Perkantoran & Sangat Sesuai & 3 \\
Pemukiman & Sesuai & 2 \\
Lahan Terbuka & Kurang Sesuai & 1
\end{tabular}

Sumber: Hasil Pemikiran, 2016

Berdasarkan Tabel 5, bahwa kriteria penskoran parameter penggunaan lahan terdiri dari 3 poin, yaitu perkantoran mendapat skor 3, daerah pemukiman mendapat skor 2, dan daerah lahan terbuka mendapat skor 1. Semakin besar skor yang didapatkan maka penentuan lokasi KCP semakin baik.

Parameter daerah perdagangan mendapat bobot 3 di karenakan faktor tersebut sangat mendukung langsung adanya penentuan lokasi baru sebuah Bank. Daerah perdagangan memerlukan sebuah Bank untuk melakukan transaksi keuangan baik untuk modal maupun untuk kelancaran bisnis, sehingga tidak heran munculah beberapa teras Bank untuk memfasilitasi daerah perdagangan.

Tabel 6. Kriteria Penskoran Parameter Lokasi Daerah Perdagangan

\begin{tabular}{llc}
\hline \multicolumn{1}{c}{ Kriteria } & \multicolumn{1}{c}{ Keterangan } & Skor \\
\hline Pasar Modern & Sangat Sesuai & 3 \\
Pasar Semi Modern & Sesuai & 2 \\
Pasar Tradisional & Kurang Sesuai & 1 \\
\hline
\end{tabular}

Sumber: Hasil Pemikiran, 2016

Berdasarkan Tabel 6, bahwa kriteria penskoran parameter kelas daerah perdagangan terdiri dari 3 poin, yaitu pasar modern dengan keterangan sangat sesuai, pasar semi modern dengan keterangan sesuai, dan pasar tradisional dengan keterangan kurang sesuai.

\section{Lokasi Daerah Pendidikan}

Parameter daerah pendidikan mendapat bobot 3 di karenakan faktor tersebut dapat dijadikan pertimbangan dalam menentukan lokasi sebuah Bank baru. Lokasi Bank yang dekat dengan pusat pendidikan bisa berkontribusi dengan lembaga tersebut dalam memudahkan transaksi keuangan seperti contoh apabila akan membayar semester.

Tabel 7. Kriteria Penskoran Parameter Lokasi Daerah Pendidikan

\begin{tabular}{llc}
\hline \multicolumn{1}{c}{ Kriteria } & \multicolumn{1}{c}{ Keterangan } & Skor \\
\hline Universitas & Sangat Sesuai & 3 \\
Sekolah Menengah Atas & Sesuai & 2 \\
Sekolah Menengah Pertama & Kurang & 1 \\
\hline
\end{tabular}

Sumber: Hasil Pemikiran, 2016

Berdasarkan Tabel 7, kriteria penskoran parameter lokasi daerah pendidikan terdiri dari 3 poin, yaitu lokasi KCP dengan Universitas dengan keterangan sesuai, lokasi KCP dekat dengan Sekolah Menengah Atas dengan keterangan sesuai, dan lokasi KCP dekat dengan Sekolah Menengah Pertama dengan keterangan kurang sesuai.

Parameter jumlah penduduk mendapat bobot 3. Letak suatu Bank yang dekat dengan penduduk membantu masyarakat dalam mewadahi untuk melakukan transaksi keuangan. Penentuan lokasi Bank perlu memperhatikan jumlah penduduk agar pihak perbankan mendapatkan keuntungan dari banyaknya nasabah. 
Moh. Dendy F B dan Rendra Zainal Maliki/Majalah Geografi Indonesia Vol. 32, No.2, September 2018 : 184 - 197

Tabel 8. Kriteria Penskoran Parameter Jumlah Penduduk

\begin{tabular}{llc}
\hline Kriteria & Keterangan & Skor \\
\hline Padat & Sangat Sesuai & 3 \\
Sedang & Sesuai & 2 \\
Rendah & Kurang Sesuai & 1
\end{tabular}

Sumber: Hasil Pemikiran, 2016

Berdasarkan Tabel 8, maka dapat disimpulkan bahwa kriteria penskoran jumlah penduduk terdiri dari 3 poin, yang pertama ialah jumlah penduduk padat lebih dari 5000 pupulasi itu mendapat keterangan sangat sesuai, jumlah penduduk sedang lebih dari 3000 pupulasi itu mendapat keterangan sesuai, dan jumlah penduduk rendah kurang dari 3000 pupulasi itu mendapat keterangan kurang sesuai.

Parameter pendapatan penduduk mendapat bobot 3. Parameter pendapatan penduduk dipilih karena dapat mendukung dalam penentuan lokasi baru. Penentuan lokasi Bank yang baru perlu memperhatikan pendapatan ekonomi penduduk agar segmen pasar tetap berjalan. Tentunya sebelum melakukan penentuan lokasi baru pihak Bank telah memperoleh informasi yang mendukung kenapa harus ekonomi penduduk di daerah tersebut yang akan dibuat lokasi.

Tabel 9. Kriteria Penskoran Parameter Tingkat Pendapatan Penduduk

\begin{tabular}{|c|c|c|}
\hline Kriteria & Keterangan & Skor \\
\hline Tinggi & Sangat Sesuai & 3 \\
\hline Sedang & Sesuai & 2 \\
\hline Rendah & Kurang Sesuai & 1 \\
\hline
\end{tabular}

Sumber: Hasil Pemikiran, 2016

Berdasarkan Tabel 9, maka dapat disimpulkan bahwa kriteria penskoran parameter tingkat ekonomi penduduk terdiri dari 3 poin, yaitu tinggi dengan tingkat pendapatan penduduklebih dari Rp.4.000.000 mendapat keterangan sangat sesuai, kriteria sedang dengan tingkat pendapatan penduduk dari Rp.2.000.000-4.000.000 mendapat keterangan sesuai dan yang terakhir kriteria rendah dengan tingkat pendapatan penduduk kurang dari Rp. 2.000.000 mendapat keterangan kurang sesuai.

Parameter kelas jalan mendapat bobot 2. Faktor fisik dalam penentuan lokasi baru bukan merupakan faktor utama. Pihak Bank lebih memilih faktor ekonomi dalam penentuan lokasi baru. Lokasi kelas jalan yang dipilih apabila suatu Bank terletak di jalan Nasional maka akan lebih memudahkan nasabah untuk datang, sedangkan jika suatu Bank terletak di Jalan yang sempit maka nasabah akan mempehitungkan untuk datang.
Tabel 10. Kriteria Penskoran Parameter Kelas Jalan

\begin{tabular}{llc}
\hline \multicolumn{1}{c}{ Kriteria } & Keterangan & Skor \\
\hline Jalan Nasional & Sangat Sesuai & 3 \\
Jalan Propinsi & Sesuai & 2 \\
Jalan Kabupaten / Kecamatan & Kurang Sesuai & 1 \\
\hline Sumber: Hasil Pemikiran, 2016 &
\end{tabular}

Berdasarkan Tabel 10, maka dapat disimpulkan bahwa kriteria penskoran parameter kelas jalan terdiri dari 3 poin, yaitu jalan Nasional dengan keterangan sangat sesuai, jalan Propinsi dengan keterangan sesuai, dan jalan Kabupaten/Kota dengan keterangan kurang sesuai.

Parameter kesesuaian lokasi mendapat bobot 3 di karenakan faktor tersebut secara langsung berhubungan dengan efektifitas penentuan letak dimana KCP tersebut berada. Lokasi KCP yang dekat dengan penduduk akan memudahkan penduduk untuk melakukan transaksi keuangan. Jarak yang dekat dengan masyarakat, akan memudahkan kepada masyarakat untuk melakukan transaksi keungan dan akan menguntungkan bagi pihak Bank secara finansial.

Tabel 11. Kriteria Penskoran Parameter Kesesuaian Lokasi

\begin{tabular}{|c|c|c|}
\hline Kriteria & Keterangan & Skor \\
\hline $\begin{array}{l}\text { Lokasi yang sangat } \\
\text { menguntungkan } \\
\text { secara ekonomi maupun } \\
\text { kenyamanan konsumen }\end{array}$ & Sangat Sesuai & 3 \\
\hline $\begin{array}{l}\text { Lokasi yang menguntungkan } \\
\text { secara ekonomi dan } \\
\text { konsumen cukup nyaman }\end{array}$ & Sesuai & 2 \\
\hline $\begin{array}{lr}\text { Lokasi } & \text { kurang } \\
\text { menguntungkan } & \text { secara } \\
\text { ekonomi dan kurang nyaman } \\
\text { bagi konsumen }\end{array}$ & Kurang & 1 \\
\hline
\end{tabular}

Sumber: Hasil Analisis, 2016

Berdasarkan Tabel 11, maka dapat disimpulkan bahwa kriteria penskoran parameter kesesuaian lokasi terdapat 3 kriteria, yaitu lokasi yang sangat menguntungkan secara ekonomi maupun kenyamanan konsumen dengan keterangan sangat sesuai mendapat skor 3, lokasi yang menguntungkan secara ekonomi dan konsumen cukup nyaman dengan keterangan sesuai mendapat skor 2 dan yang terakhir adalah lokasi kurang menguntungkan secara ekonomi dan kurang nyaman bagi konsumen dengan keterangan kurang sesuai mendapat skor 1 .

\section{HASIL DAN PEMBAHASAN}

\section{Lokasi Daerah Industri}

Lokasi KCP BRI yang ada di Kecamatan Coblong, Sukajadi, dan Lembang berada di daerah dekat sebaran industri. Sebaran industri paling banyak tersebar di 
sekitar KCP BRI Lembang sedangkan untuk di Sukajadi dan Coblong tidak terlalu banyak. Lokasi KCP BRI yang dibangun dekat dengan industri akan memudahkan karyawan industri atau orang yang akan bertansaksi ke Bank. Dari analisis peta yang telah dibuat bahwa sebaran daerah industri merupakan faktor yang mempengaruhi sebuah KCP BRI baru akan didirikan (Gambar 2).

Di wilayah Lembang KCP BRI cukup berdekatan dengan industri dengan sebaran industri yang lebih banyak ke sebelah timur. Dapat dilihat juga di wilayah Sukajadi dan Coblong keberadaan industri tersebar di beberapa titik dan diikuti juga oleh keberadaan KCP di kedua wilayah tersebut. Kemudahan akses transaksi dalam perekonomian yang dibutuhkan oleh industri karena dekatnya dengan KCP BRI tentu sangat memudahkan nasabah yang berasal dari kalangan pekerja industri. Ini merupakan pangsa pasar yang bagus bagi keberlangsungan KCP BRI.

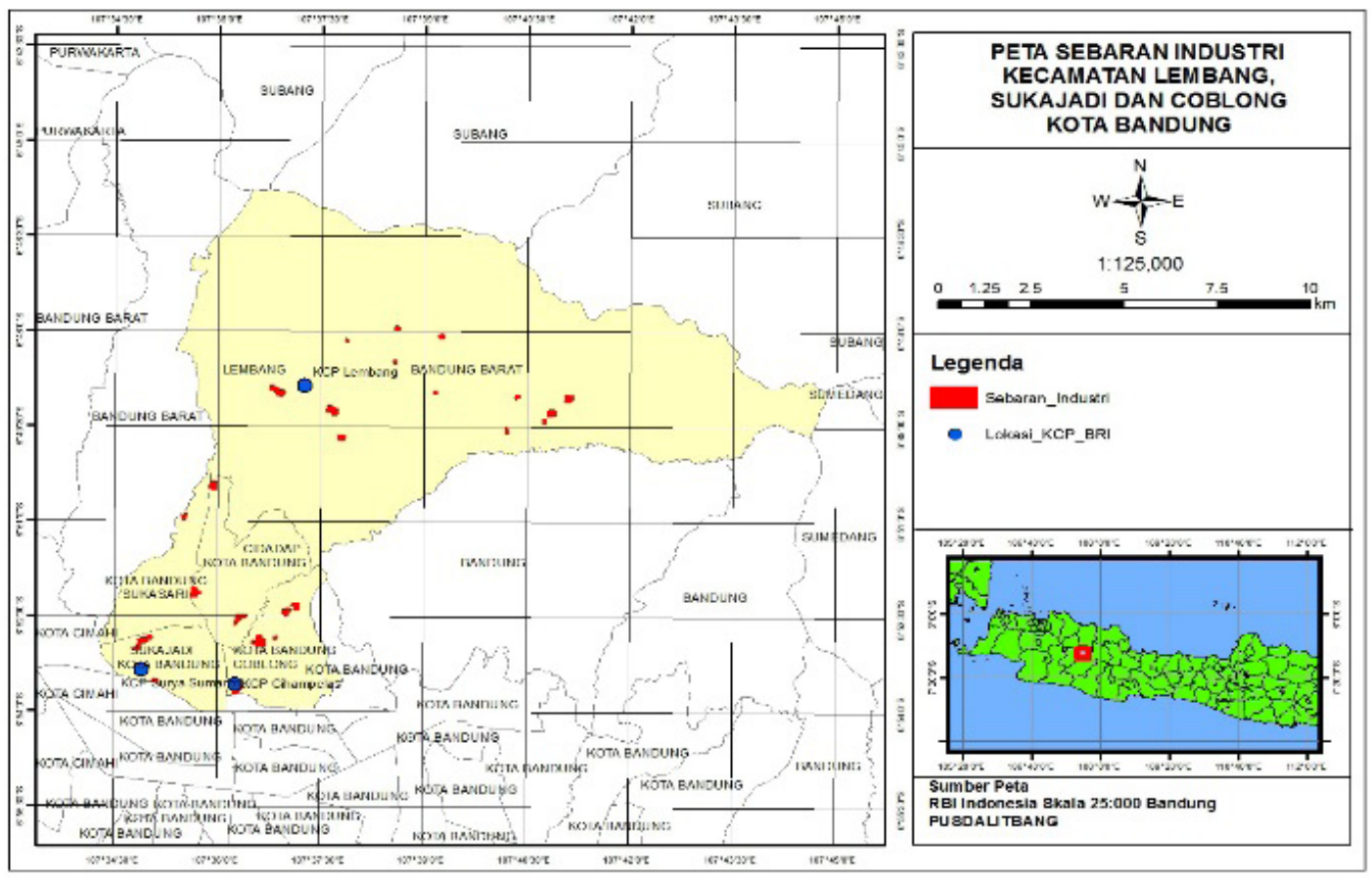

Gambar 1. Peta Sebaran Lokasi Industri

\section{Lokasi Penggunaan Lahan}

Penggunaan lahan dari peta parameter ini merupakan penggunaan lahan terbangun sebagai penentuan parameter-parameter dalam menentukan lokasi KCP Bank BRI yaitu perdagangan dan jasa, institusi pendidikan dan perkantoran, permukiman dan industri. Lokasi yang sesuai dapat menguntungkan pihak Bank sedangkan lokasi yang tidak sesuai pihak Bank tidak akan mendapatkan keuntungan yang maksimal.

Dari peta yang telah dibuat dapat dilihat bahwa penggunaan lahan yang digunakan cukup beragam (Gambar 2). Di Kecamatan Sukajadi, Coblong, Sukasari dan Cidadap sebagian wilayahnya merupakan wilayah yang terbangun baik perumahan, pusat perbelanjaan maupun kantor-kantor kedinasan. Di Kecamatan Cidadap ke sebelah timur laut nya ada sedikit penggunaan lahan yang dipakai oleh semak belukar dan juga tegalan atau ladang. Keberadaan Cidadap yang dekat dengan Lembang yang memang masih memiliki beberapa ruang terbuka hijau baik oleh kebun-kebun maupun semak-semak belukar.

Lokasi KCP BRI di tiap Kecamatan yaitu Coblong, Sukajadi dan Lembang terlihat menempati wilayah yang ditutupi oleh penggunaan lahan terbangun. Wilayah terbangun tersebut merupakan wilayah yang dipenuhi bangunan-bangunan aktivitas manusia atau masyarakat dengan ekonomi tinggi, kantor-kantor maupun kegiatan ekonomi. Keberadaan KCP BRI di wilayah terbangun ini akan sangat membantu bagi nasabah untuk bertransaksi di BRI. Dekatnya lokasi dengan KCP BRI sangat menguntungkan baik bagi nasabah maupun bagi BRI. Dengan mudahnya mencapai lokasi KCP BRI, maka nasabah tidak terlalu banyak untuk mengeluarkan biaya transportasi menuju lokasi KCP. Bila kemudahan akses ini terus berlangsung maka kepuasan nasabah akan semakin meningkat. Ini juga akan berpengaruh pada meningkatnya jumlah nasabah bagi BRI. 


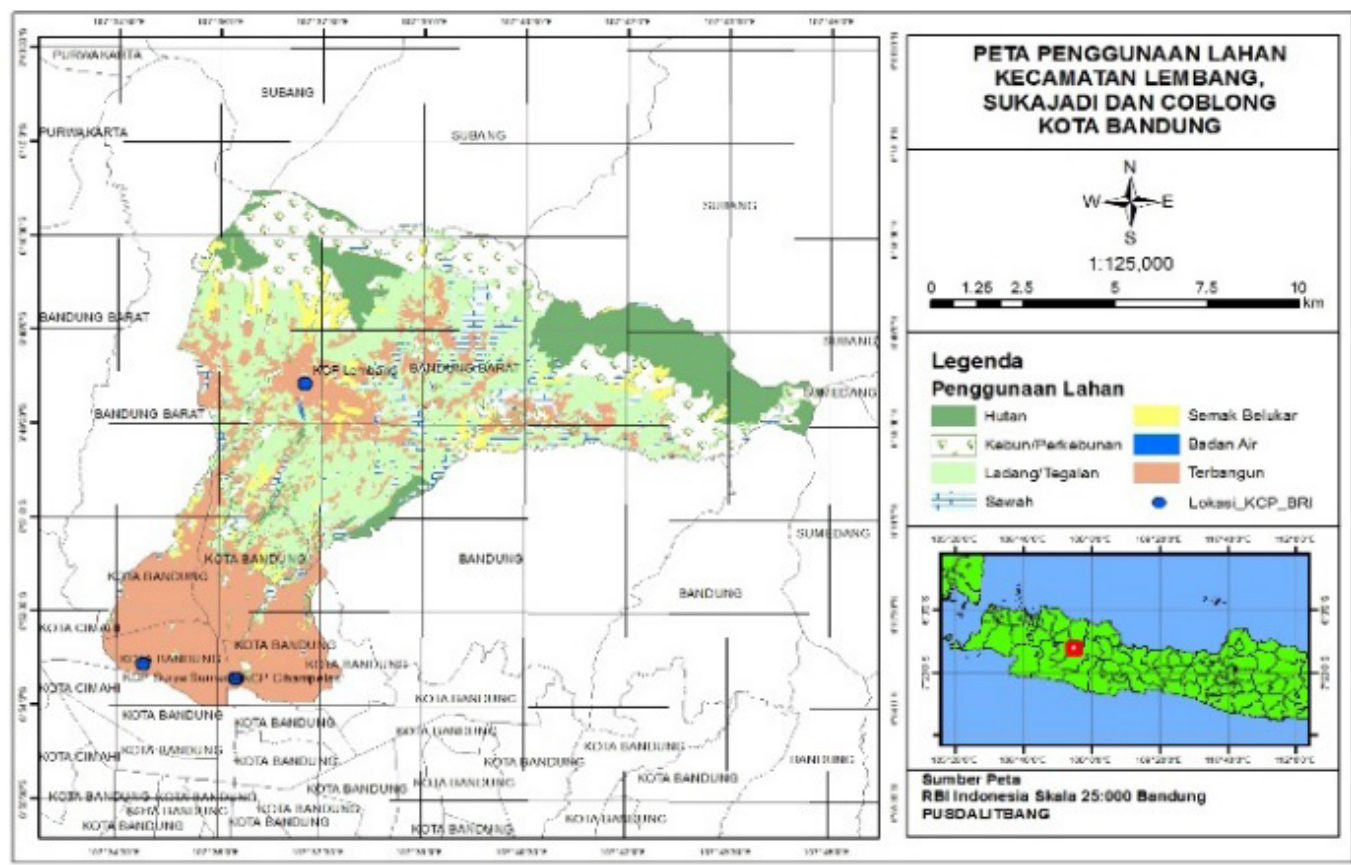

Gambar 2. Peta Sebaran Penggunaan Lahan

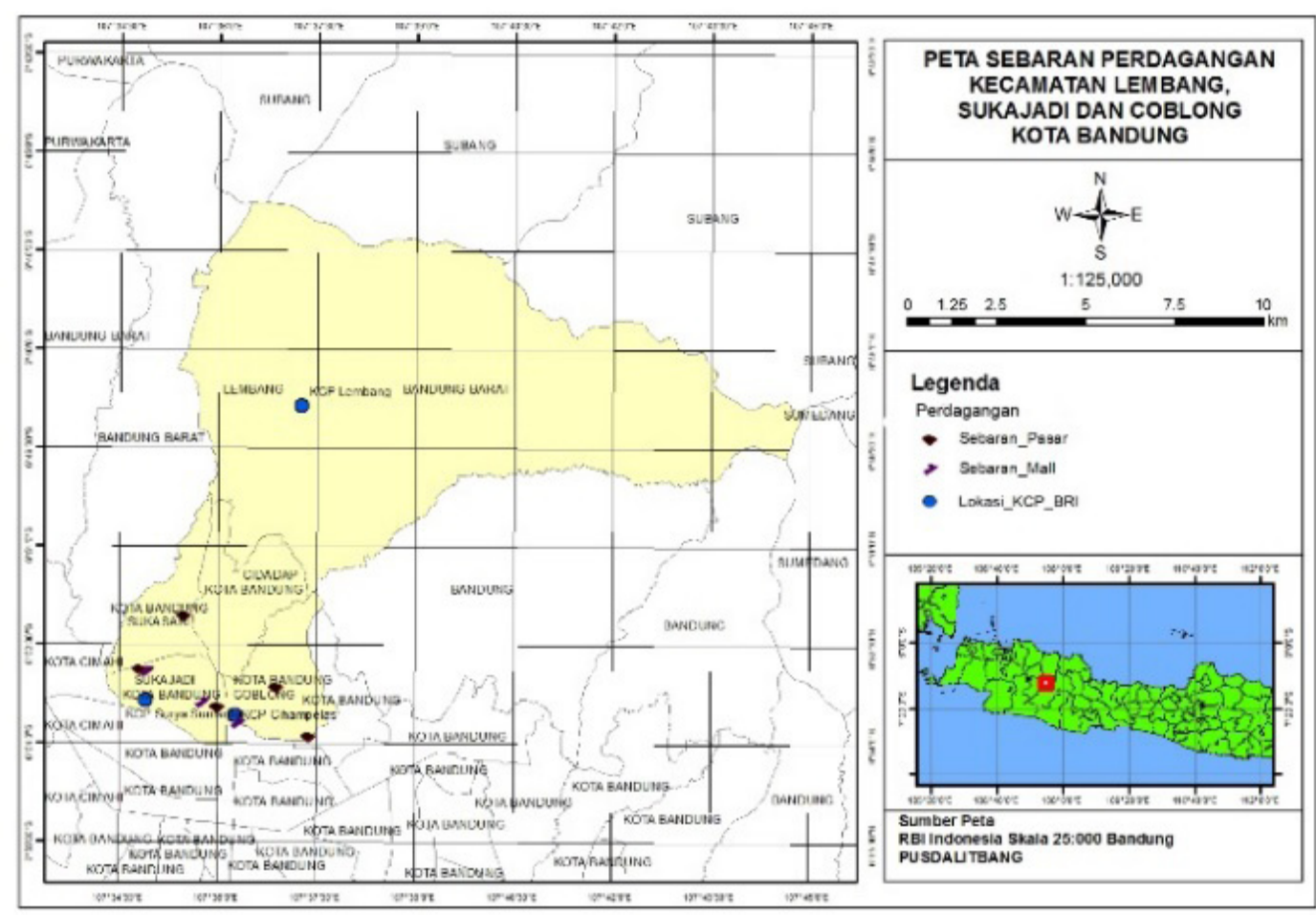

Gambar 3. Peta Sebaran Perdagangan

\section{Peta Sebaran Perdagangan}

Peta sebaran perdagangan merupakan peta dari sebaran pasar dan mall yang ada di Kecamatan Coblong, Sukajadi, dan Lembang yang ada di wilayah unit kerja Bank BRI Setiabudi (Gambar 3). Peta sebaran perdagangan dijadikan perameter untuk menentukan Kantor Cabang Pembantu (KCP) BRI karena sangat berpengaruh kepada masyarakat yang akan bertansaksi di Bank. Sebaran pasar terdapat di semua Kecamatan unit kerja KCP BRI sedangkan untuk mall hanya berada di Kecamatan Coblong dan Sukajadi. Sebaran pasar dan mall dipilih sebagai parameter karena sebaran perdagangan pasti memerlukan kehadiran sebuah bank untuk melakukan transaksi.

Dapat dilihat dari peta persebaran perdagangan bahwa terdapat dua jenis sektor perdagangan yaitu 
pasar dan mall. Pasar tersebar di beberapa Kecamatan seperti di Kecamatan Coblong terdapat dua pasar, Kecamatan Sukajadi terdapat dua pasar, dan Kecamatan Sukasari terdapat satu pasar. Sedangkan mall terdapat di Kecamatan Coblong dan di Kecamatan Sukajadi. Terlihat bahwa lokasi KCP BRI berdekatan dengan sektor perdagangan. KCP BRI di Kecamatan Coblong berdekatan dengan mall, sedangkan pasar agak jauh namun masih dalam satu Kecamatan yang masih bisa dijangkau. Lalu ada KCP BRI di Kecamatan Sukajadi berdekatan dengan mall dan pasar, dari KCP BRI terdapat di sebelah utara dan di sebelah timur masingmasing dua sektor perdagangan mall dan pasar. Sedangkan di Kecamatan Lembang KCP BRI berdekatan dengan pasar tradisional. Dekatnya KCP BRI di tiap Kecamatan tersebut dengan sektor perdagangan akan sangat mempengaruhi keberadaan KCP karena pangsa pasar dapat memberikan income yang tinggi bagi pelaku usaha.

\section{Peta Sebaran Pendidikan}

Peta sebaran pendidikan merupakan salah satu parameter yang dijadikan sebagai peta dalam menentukan lokasi KCP BRI baru (Gambar 4). Sebaran pendidikan seperti SMP, SMA, dan Universitas memerlukan sebuah Bank untuk melakukan transaksi pembayaran misalnya untuk pembayaran semester. Sebaran pendidikan berpengaruh dalam menentukan sebuah Lokasi KCP BRI baru dimana kegiatan akademik selalu memerlukan bank dalam setiap kegiatan pembayaran.

Pada peta lokasi sebaran pendidikan mulai dari SMP, SMA, dan Universitas tersebar hampir di semua
Kecamatan kecuali Kecamatan Lembang yang tidak terdapat Universitas. Perlunya mendirikan sebuah KCP BRI baru didekat SMP dan SMA karena zaman sekarang peserta didik sebagian besar telah beralih menggunakan tabungan di rumah menjadi tabungan Bank. Untuk itu pihak Bank telah melakukan analisis ketika akan membangun lokasi KCP BRI baru di dekat dengan sebaran SMP dan SMA. Sebaran pendidikan yang selanjutnya adalah Universitas. Saat ini banyak Universitas yang bekerjasama dengan Bank dalam memudahkan transaksi seperti kartu tanda mahasiswa (KTM) yang telah dikombinasikan dengan ATM sebuah Bank. Apabila ada kerjasama antara pihak Bank dan Universitas maka pihak Bank akan mendapatkan keuntungan dari transaksi yang dilakukan mahasiswa tersebut.

Lokasi KCP BRI di Kecamatan Coblong dekat dengan semua sebaran pendidikan mulai dari SMP, SMA, dan Unversitas. Untuk di Kecamatan Sukajadi juga dekat dengan semua sebaran pendidikan mulai dari SMA, SMA, dan Universitas. Sedangkan untuk di Kecamatan Lembang hanya dekat dengan sebaran SMP dan SMA. Pada peta sebaran pendidikan terlihat bahwa lokasi KCP BRI tersebar berdekatan dengan lokasi pendidikan.DiKecamatan Coblong KCPBRIberdekatan dengan lembaga pendidikan yang memanjang ke arah utara. Hal ini akan sangat menguntungkan apalagi disana ada Universitas yang hampir semua civitas akademika menggunakan layanan Bank. Di Kecamatan Sukajadi pun KCP BRI nya sangat berdekatan dengan lembaga pendidikan yang juga memanjang ke arah utara. Sedangkan di Kecamatan Lembang KCP BRI begitu berdekatan dengan SMP, terlihat SMP berada di sebelah utara dari lokasi KCP BRI.

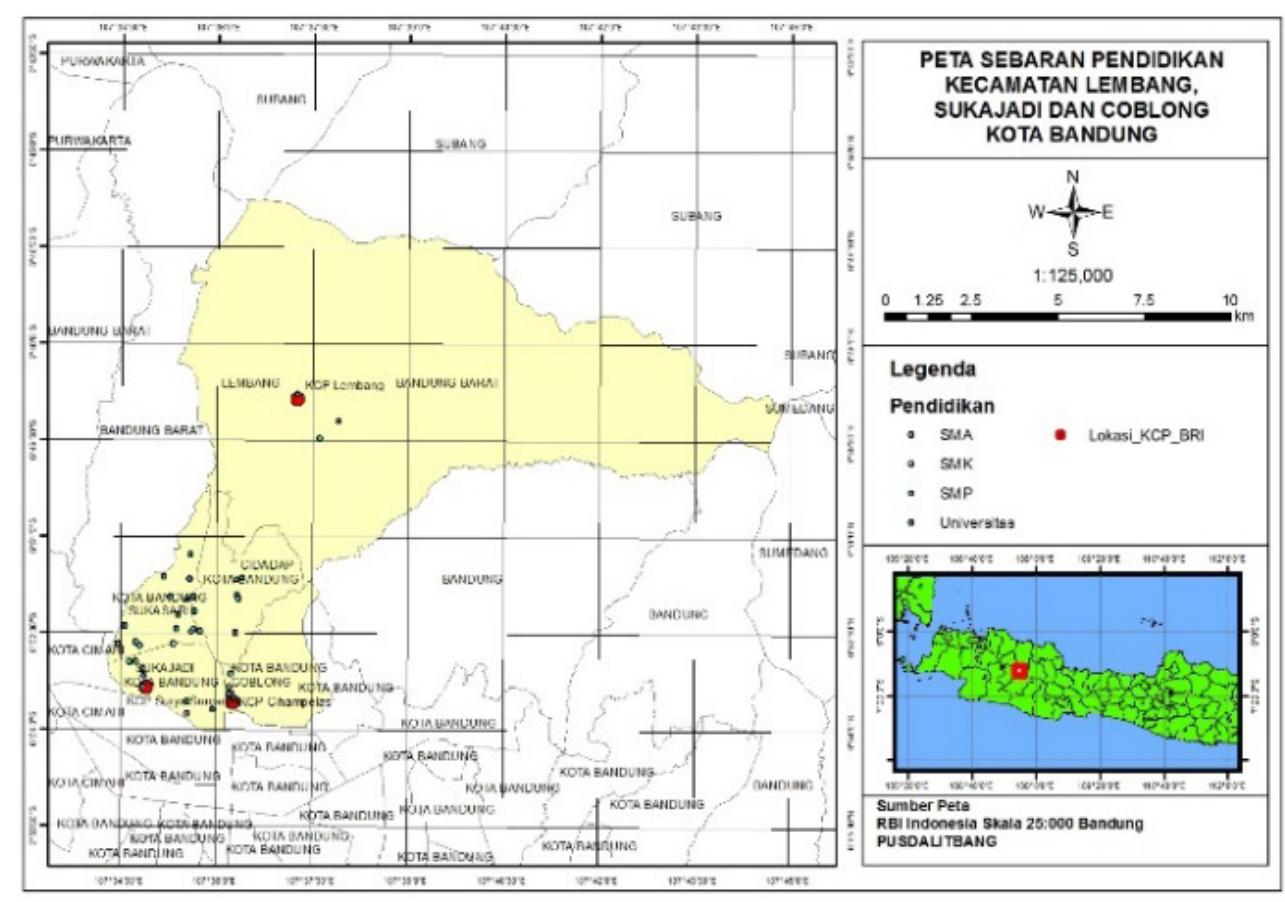

Gambar 4. Peta Sebaran Pendidikan 


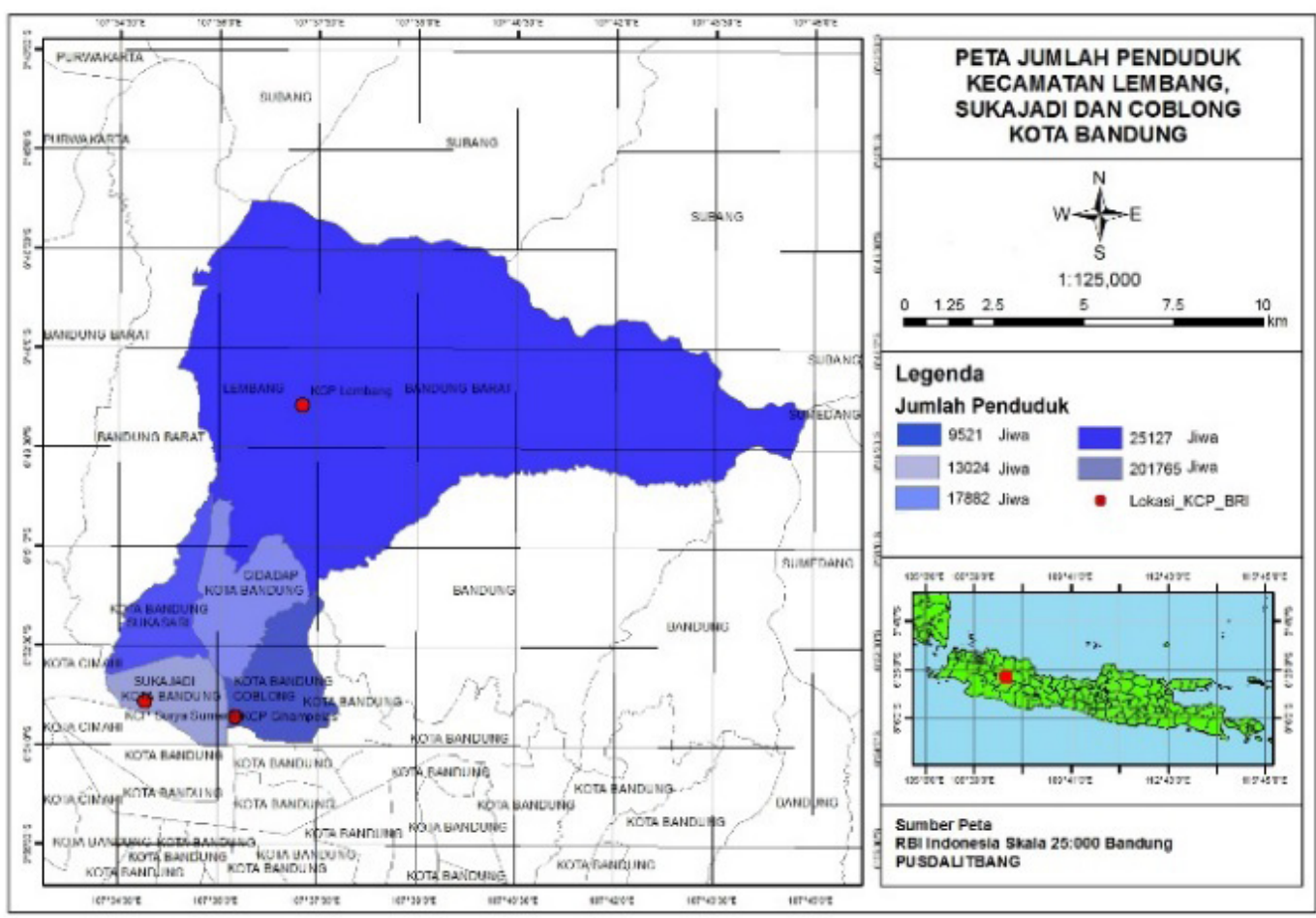

Gambar 5. Peta Jumlah Penduduk

\section{Peta Jumlah Penduduk}

Peta jumlah penduduk dijadikan parameter dalam menentukan sebuah KCP BRI (Gambar 5). Jumlah penduduk pada peta di bawah paling banyak terdapat di Kecamatan Lembang dengan 201.765 penduduk, Sukajadi dengan 25.127 penduduk, Coblong 17.882 penduduk, Sukasari 13.024 penduduk, dan Cidadap 9.521 penduduk. Sebaran jumlah penduduk yang tidak merata di setiap Kecamatan menjadikan pihak perbankan harus berfikir dengan sungguh-sungguh dalam menentukan sebuah KCP BRI baru. Apabila salah dalam menentukan sebuah lokasi KCP maka pihak bank tidak akan mendapatkan keuntungan yang maksimal. Untuk itu sebaran jumlah penduduk yang ada di wilayah unit kerja Bank BRI Setiabudi dapat dijadikan referensi dalam penentuan lokasi baru.

Jumlah penduduk di Kecamatan Lembang menempati urutan pertama dengan jumlah penduduk 201.765 jiwa. Hal itu disebabkan oleh luas wilayah Kecamatan Lembang yang sangat luas. Bahkan apabila berbicara kepadatan, dengan luas wilayah yang begitu besar dan jumlah penduduk sekitar 201.765 jiwa maka dapat dinyatakan kepadatan penduduk di wilayah kcamatan Lembang masih kurang. Untuk penempatan Lokasi KCP belum tentu sangat sesuai, karena bukan hanya faktor jumlah penduduk yang menentukan penentuan lokasi KCP, akan tetapi masih terdapat 7 parameter yang menentukan penentuan lokasi KCP itu sendiri.

Selanjutnya jumlah penduduk di wilayah Kecamatan yang berada di adiministrasi kota Bandung hampir merata jumlahnya. Penduduk di wilayah
Kecamatan Sukajadi jumlah tertinggi dan wilayah Kecamatan Cidadap dengan kategori terendah. Hal itu sesuai dengan hasil overlay beberapa peta parameter yang digunakan dalam penelitian ini, bahwa di daerah Sukajadi sangat berbeda jauh dengan di wilayah Kecamatan Cidadap. Di wilayah Sukajadi terdapat sebaran pendidikan yang banyak, sebaran pasar yang dimulai dari pasar modern seperti Paris Van Java, Yogya dll, sebaran tempat industri fasilitas kesehatan lebih jauh lengkap di bandingkan wilayah Kecamatan Cidadap.

\section{Peta Pendapatan Penduduk}

Peta pendapatan penduduk dapat dijadikan parameter dalam menentukan peta KCP BRI baru (Gambar 6). Pendapatan penduduk di setiap Kecamatan memiliki variasi berbeda dari yang terkecil di Kecamatan Lembang dan terbesar di Kecamatan Sukasari. Pada peta di bawah ini menunjukan bahwa rata-rata pendapatan penduduk di Kecamatan Sukasari adalah Rp 2.500.000, Sukajadi Rp 1.900.000, Cidadap Rp 1.700.000, Coblong 1.610.000, dan Lembang Rp 1.500.000 (BPS Kota Bandung).

Pertimbangan penentuan lokasi KCP BRI berdasarkan pendapatan penduduk karena semakin banyak penduduk yang berpenghasilan tinggi akan selalu membutuhkan Bank dalam melakukan transaksi keuangan. Bank yang didirikan dekat dengan penduduk yang berpenghasilan tinggi akan menguntungkan pihak Bank dan penduduk itu sendiri. Keberadaan Bank dan penduduk saling membutuhkan satu sama lain. Pendapatan penduduk merupakan salah satu alasan 
pihak perbankan mendirikan KCP baru. KCP yang didirikan nantinya akan mewadahi penduduk apabila akan melakukan transaksi keuangan seperti deposit, meminjam uang, dan lain sebagainya. Keberadaan kantor cabang pembantu (KCP) didirikan karena keberadaan Unit pada sebuah Bank tidak mampu lagi mewadahi transaksi penduduk.

Berdasarkan hasil analisis dan overlay pada peta pendapatan penduduk di wilayah sebaran kantor cabang pembantu bank BRI, wilayah Kecamatan Sukasari mendapat urutan tertinggi pendapatan penduduknya yaitu sebesar Rp 2.500.000, di susul oleh Kecamatan Sukajadi Rp 1.900.000, selanjutnya Kecamatan Cidadap $\mathrm{Rp}$ 1.700.000, Coblong 1.610.000, dan Lembang Rp 1.500.000. Pendapatan tersebut didapatkan dariberbagai sumber mata pencharian, apabila dikaitakan dengan peta penggunaan lahan, wilayah Kecamatan Lembang masih di dominasi petani, wilayah Kecamatan Coblong, Sukajadi, Sukasari dan Cidadap masih heterogen dan seimbang mata pencaharian penduduknya.

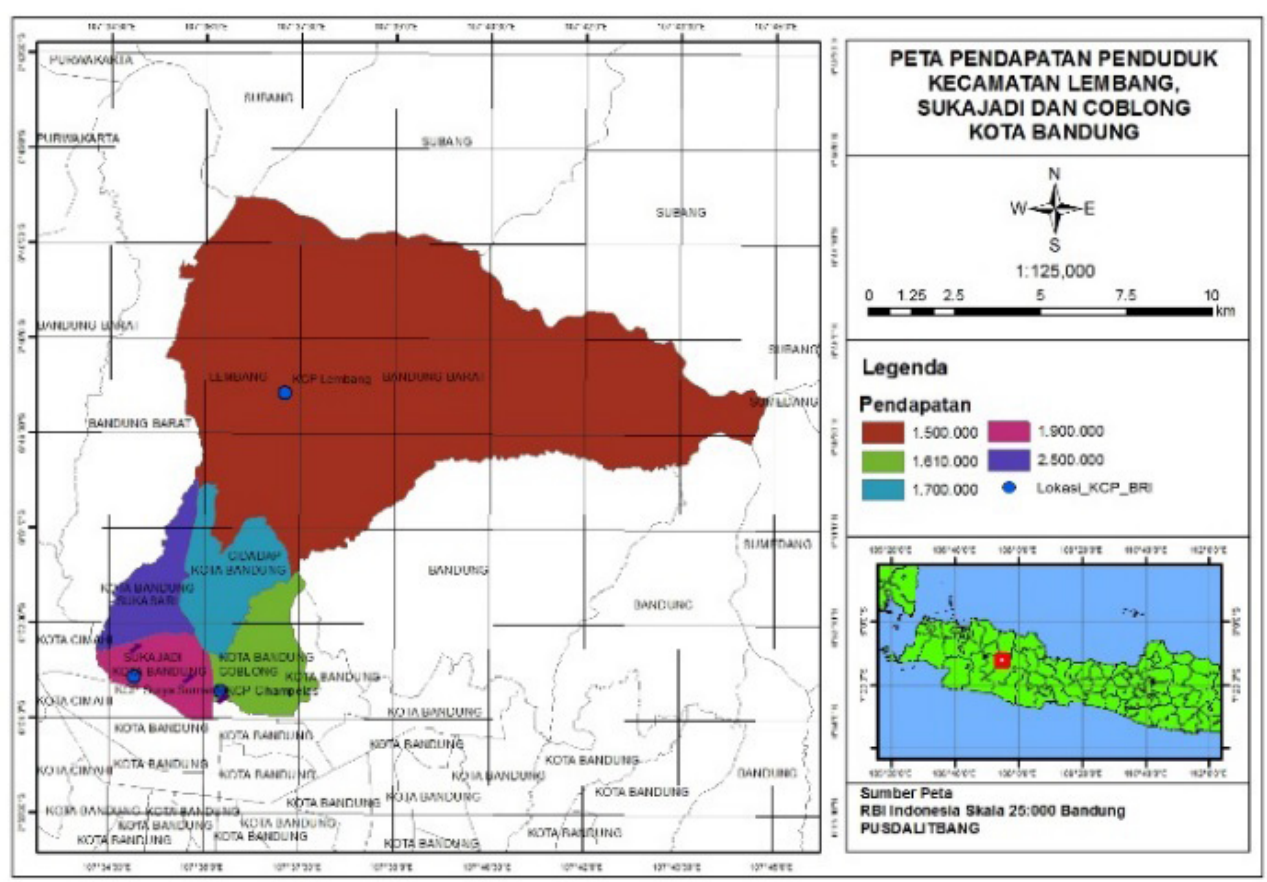

Gambar 6. Peta Pendapatan Penduduk

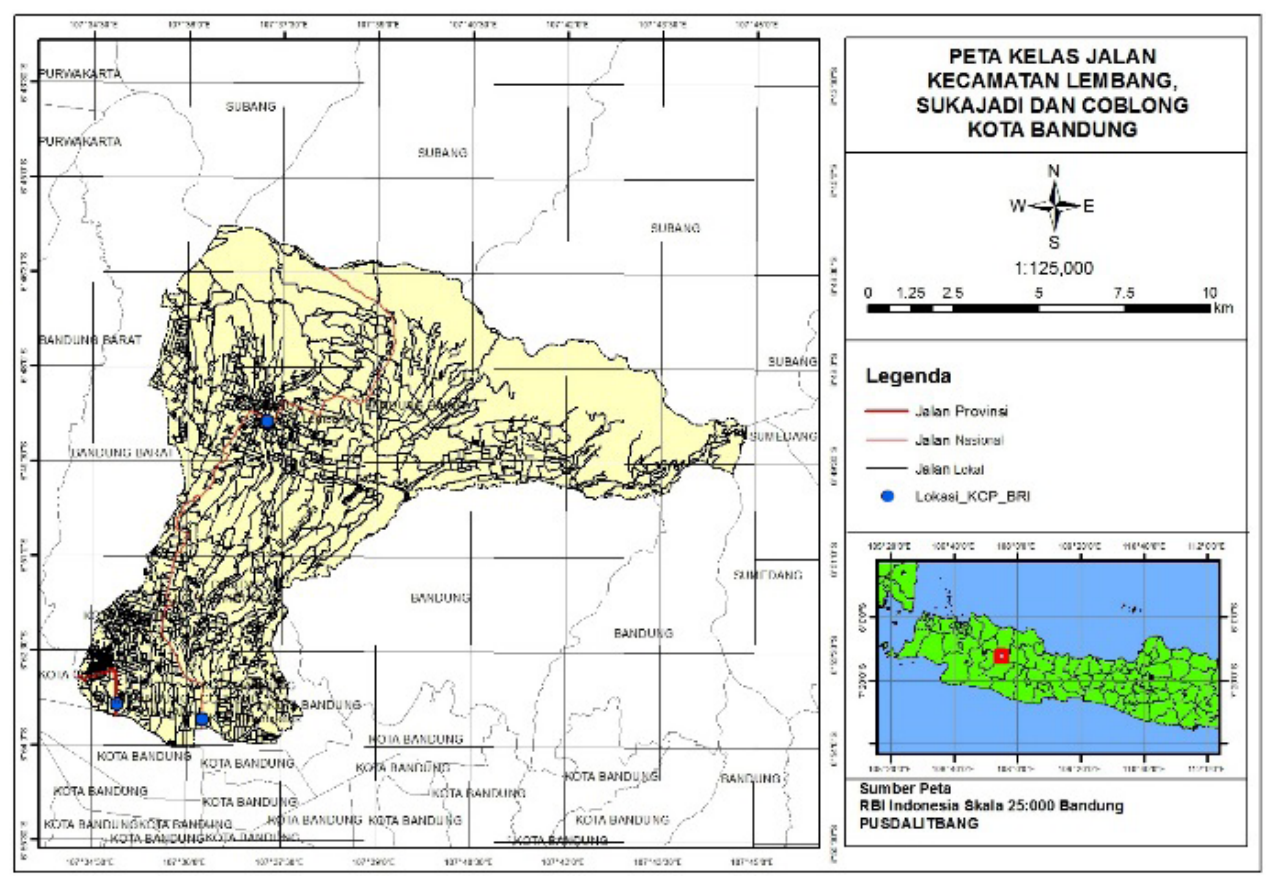

Gambar 7. Peta Kelas Jalan 


\section{Peta Kelas Jalan}

Kelas jalan kolektor dan arterti tidak selalu dijadikan pertimbangan oleh pihak perbankan dalam mendirikan suatu Bank tetapi lebih kepada pangsa pasar (Gambar 7). Lokasi kantor cabang (KC) BRI unit Setiabudi memiliki tiga kantor cabang pembantu (KCP) yang berada di jalan Cihampelas yaitu terletak di Kecamatan Coblong, di jalan Surya Sumantri yaitu terletak di Kecamatan Sukajadi, dan di jalan Raya Lembang terletak di Kecamatan Lembang. Penentuan kelas jalan pada peta tersebut menjadi faktor kedua dalam menentukan suatu KCP Bank dikarenakan di jalan sekunder pun letak KCP dapat didirikan. Oleh karena itu, pihak perbankan dalam menentukan suatu KCP Baru selalu melihat pangsa pasar bukan melihat kelas jalan arteri atau sekunder.

Berdasarkan peta kelas jalan, lokasi KCP BRI tidak semua berada di kelas jalan Nasional, hanya KCP BRI Lembang dan Coblong yang berada di lokasi jalan nasional. Sedangkan KCP BRI Surya Sumantri yang berada di wialayah Kecamatan Sukajadi berada pada kelas jalan Provinsi. Pertimbangkan dalam penentuan lokasi startegis KCP BRI ini, dikarenakan kelas jalan hanya sebagai faktor pembantu dalam menentuan lokasi KCP sedangkan yang menjadi faktor utama adalah potensi pasar yang berkaitan dengan pendapatan, pusat keramaian, lokasi industri, pendidikan dll.

\section{Peta Kesesuaian Lokasi Kantor Cabang Pembantu (KCP) BRI}

Berdasarkan hasil analisis dari beberapa peta parameter lokasi sebaran daerah industri, penggunaan lahan, daerah perdagangan, daerah pendidikan, jumlah penduduk, pendapatan paenduduk, dan kelas jalan maka didapatkan lokasi kantor cabang pembantu (KCP) BRI baru. Beberapa peta parameter tersebut di overlay sehingga muncul daerah mana saja yang sesuai untuk didirikan sebuah KCP baru (Gambar 8).

Penentuan kesesuaian lokasi KCP BRI dibagi menjadi empat kelas interval yaitu untuk $\mathrm{N}=$ tidak sesuai, S1 = sangat sesuai, S2 = sesuai, dan S3 = kurang sesuai. Jika melihat peta yang berwarna merah atau $\mathrm{N}$ maka daerah yang tidak sesuai sangat sedikit cakupan wilayahnya. Untuk peta yang berwarna kuning atau S1 cakupan wilayahnya agak sedikit lebih banyak dari pada yang berwarna merah. Peta sangat sesuai atau S1 tersebar di Kecamatan Sukajadi, Coblong, dan Sukasari. Untuk peta yang berwarna biru muda atau S2 cakupan wilayahnya lebih banyak dibandingkan S1 dan N. Peta S2 atau sesuai mencakup semua Kecamatan wilayah unit kerja Bank BRI cabang Setiabudi seperti Kecamatan Coblong, Sukajadi, Sukasari, Cidadap, dan Lembang. Untuk peta yang berwarna hijau muda atau S3 wilayah cakupannya sangat banyak. Peta tersebut mencakup semua Kecamatan yaitu Coblong, Sukajadi, Sukasari, Cidadap, dan Lembang.

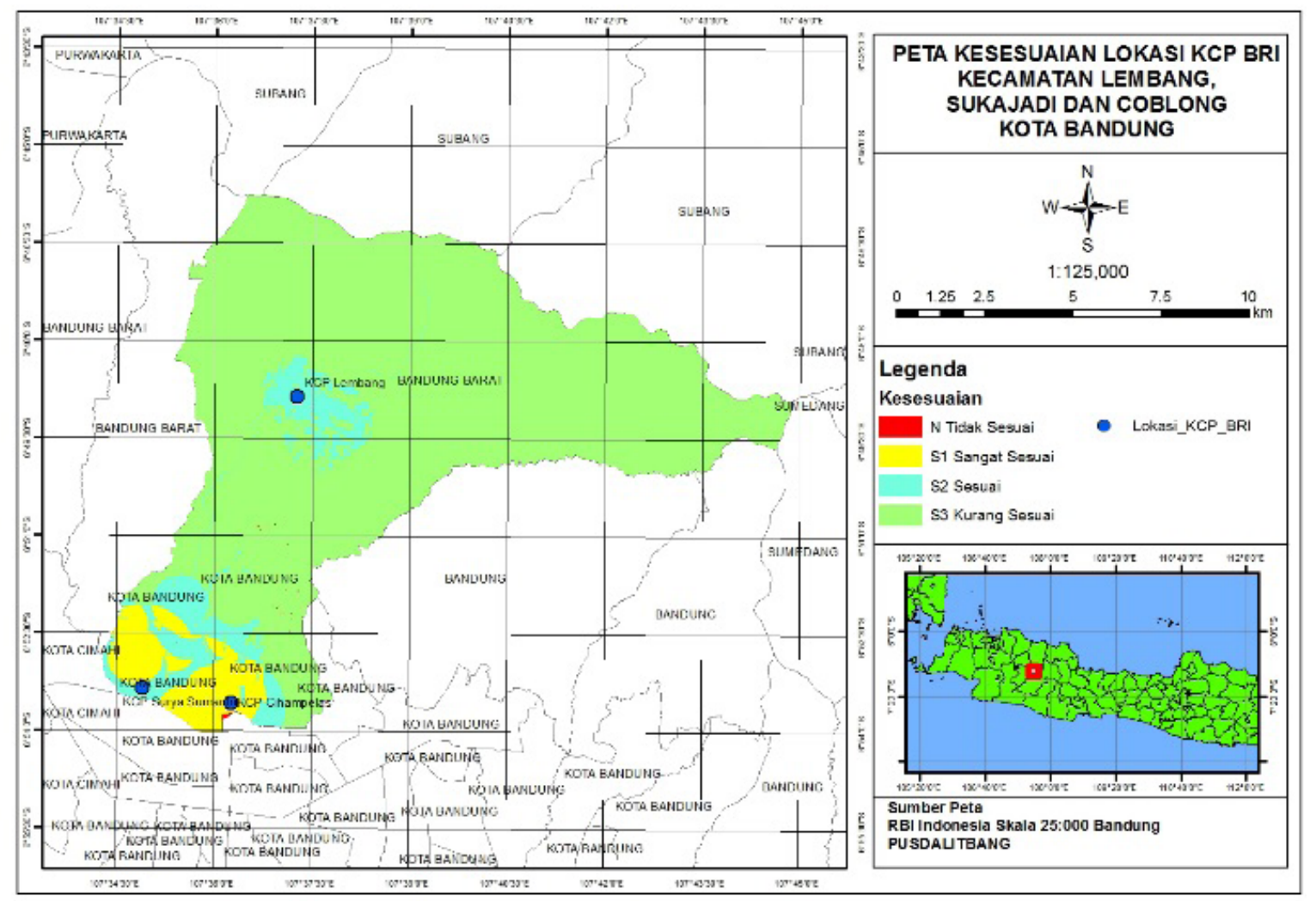

Gambar 8. Peta Kesesuaan Lokasi Kantor Cabang Pembantu Bank BRI 
Berdasarkan hasil analisis dan overlay dapat disimpulkan bahwa dari 3 lokasi KCP BRI di wilayah unit kerja kantor cabang Bank BRI Setiabudi hanya 2 lokasi KCP BRI yang dapat kriteria sangat sesuai yaitu KCP BRI Cihampelas yang berada di wialayah Kecamatan Coblong dan KCP BRI Suraya Sumantri yang berada di wilayah Kecamatan Sukajadi. Sedangkan KCP BRI Lembang hanya mendapat kriteria sesuai. Hal itu sesuai dengan hasil analisis menggunakan beberapa parameter-parameter yang mendukung dalam penentuan lokasi KCP BRI.

Hal yang mendukung KCP BRI Cihampelas dan Surya Sumantri mendapat keriteria sangat sesuai adalah dari pendapatan penduduk, sebaran pendidikan, sebaran industri, sebaran pasar atau pusat perdagangan, dan kelas jalan. Sedangkan untuk KCP BRI Lembang berdasarkan hasil analisis dan overlay yang menjadi penilaian kurang adalah karena sedikit atau kurangnya sebaran pendidikan, terletak jauh dari sebaran industri, dan kurang untuk sebaran pasar modern. Selain itu terdapat wialayah yang sangat sesuai untuk dijadikan atau dibangun lokasi baru KCP BRI, yaitu di wilayah Kecamatan Sukasari.

\section{KESIMPULAN}

Berdasarkan hasil analisis penentuan lokasi KCP Bank BRI menggunakan Sistem Informasi Geografis dapat disimpulkan bahwa lokasi KCP Bank BRI di wilayah unit kerja Kantor Cabang Setiabudi baru yaitu KCP BRI Lembang, KCP BRI Cihampelas, dan KCP BRI Surya Sumantri tidak seluruhnya mendapat klasifikasi sangat sesuai. Berdasarkan hasil overlay terdapat dua KCP yang mendapat kategori sangat sesuai yaitu KCP Cihampelas yang berada di wilayah Kecamatan Coblong dan KCP Surya Sumantri yang berada di wilayah Sukajadi. Selanjutnya terdapat satu daerah lagi yang mendapat klasifikasi sangat sesuai apabila dibangun KCP BRI yaitu di wilayah Kecamatan Sukasari. Akan tetapi di wilayah Sukasari terdapat Kantor Cabang BRI Setiabudi yang merupakan induk dari tiga KCP yang menjadi unit analisis dalam penelitian ini. adapun beberapa rekomendasi dalam penelitian ini di antaranya adalah (a) Pendirian lokasi Kantor Cabang Pembantu (KCP) Bank harus memperhatikan banyak faktor, diantaranya faktor alam dan faktor manusia dan (b) Kantor Cabang Pembantu (KCP) Bank BRI dapat ditambah yaitu berdasarkan hasil overlay terdapat wilayah yang sangat cocok untuk dibangun Kantor Cabang Pembantu Bank BRI.

\section{UCAPAN TERIMAKASIH}

Dalam rangka penulisan artikel ini, penulis banyak mendapatkan bantuan berupa doa, dukungan, nasehat, arahan, bimbingan, ide, ilmu, pengalaman, dan hal lain yang bermanfaat dari berbagai pihak. Oleh karena itu, dalam kesempatan ini penulis mengucapkan terimakasih yang sebesar-besarnya kepada pembimbing artikel dan para staf dosen di Prodi Pendidikan Geografi
Sekolah Pascasarjana Universitas Pendidikan Indonesia serta pihak Bank BRI Kantor Cabang Setiabudi Kota Bandung.

\section{DAFTAR PUSTAKA}

Benoit D and G P Clarke. (1997). Assessing GIS for retail location planning School of Geography. University of Leeds, UK. Journal Retailing and Comsumer Services, Vol. 4 (4): 239-258.

Capello, Roberta. (2011). Location, Regional Growth and Local Development Theories. AESTIMUM, Vol. (58): 1-25.

Chang, Kang Sung. (2002). Introduction Geographic Information Systems. The McGraw-Hill Companies, Inc: New York, United States of America.

Fauzi, Y. Susilo, B. Mayasari, Z.M. (2009). Analisis Kesesuaian Lahan Wilayah Pesisir Kota Bengkulu Melalui Perancangan Model Spatial dan Sistem Informasi Geografis (SIG). Forum Geografi, Vol. 23(2): 101-111.

Hutagaol, V. Bambang, S. Arief, L. (2015). Penentuan Potensi Lokasi ATM BNI Menggunakan Analytical Hierarchy Process (AHP) Dan Sistem Informasi Geografis (Studi Kasus: Kecamatan Tembalang). Jurnal Geodesi Undip, Vol. 4(2): 25-32.

Kotler, Philip. (1996). Marketing Manajement: Analysis, Planning, Implementation, and Control. (Manajemen Pemasaran) ed. 6. Jakarta: Erlangga.

Mohamed, Y. Mohamad, Katheeri. F, dan Salam. A. (2015). A GIS Application for Location Selection and Customers' Preferences for Shopping Malls in $\mathrm{Al}$ Ain City; UAE. American Journal of Geographic Information System, Vol 4(2): 76-86.

Pineda, Henry Quesada, Batos M.B dan Smith R. (2017). Assesing Geographical Information Systems in Marketing Applications for The Wood Products Industry. BioProducts Business, Vol. 2(1): 14-22.

Prahasta, Eddy. (2009). Sistem Informasi Geografis Konsep-Konsep Dasar. Bandung. Informatika Bandung.

Sugiyono. (2011). Metode Penelitian Pendidikan Pendekatan Kuantitatif, Kualitatif dan R\&D. Bandung: Penerbit Alfabeta Bandung.

Syavitra, Rino. (2009). Analisis Lokasi Nasabah Potensial Bank Nagari Di Kota Depok. Depok: Universitas Indonesia.

Turk, T. Kitapci, O dan Dortyol. I. T. (2014). The Usage of Geographical Information Systems (GIS) in the Marketing Decision Making Process: A Case Study for Determining Supermarket Locations. ProcediaSocial and Behavioral Sciences, Vol 148: 227 - 235.

Undang-Undang Republik Indonesia Nomor 10 Tahun 1998 Tentang Perbankan. 